\title{
Acute toxicity and anti-inflammatory activity of hydro- methanol leaves extract of Allophylus africanus Beauv in rats
}

\author{
Fatima S. Ibrahim, Zainab Mohammed, Aliyu Nuhu*, Salisu Shehu, Najma Ilyas \\ Department of Pharmacognosy and Drug Development, Ahmadu Bello University, Zaria, Kaduna State, Nigeria
}

\section{A R T I C L E IN F O}

Article Type:

Original Article

\section{Article History:}

Received: 8 October 2017

Accepted: 10 February 2018

\section{Keywords:}

Allophylus africanus

Anti-inflammatory

Acute toxicity

Carrageenan

\begin{abstract}
A B S T RA C T
Introduction: The leaves of Allophylus africanus are traditionally used for the treatment of various ailments such as arthritis, rheumatism, gout, hemorrhoids, dysentery, venereal diseases and malnutrition. This study was carried out to evaluate the acute toxicity and antiinflammatory activity of the hydro-methanol leaves extract of $A$. africanus on laboratory rats. Methods: Allophylus africanus leaves were extracted with $80 \%$ methanol using cold maceration for 5 days. The extract was subjected to phytochemical analysis, acute toxicity study and antiinflammatory evaluation using carrageenan induced paw edema in laboratory rats.

Results: The phytochemical screening of the aqueous methanol leaves extract revealed the presence of carbohydrates, tannins, steroids/triterpenes, flavonoids, alkaloids and cardiac glycosides. The extract was found to have median lethal dose (LD50) of $3807.89 \mathrm{mg} / \mathrm{kg}$ body weight orally and the aqueous methanol leaves extract at doses 250 and $1000 \mathrm{mg} / \mathrm{kg}$ produced significant anti-inflammatory effect at the $3 \mathrm{rd}$, 4 th and 5 th hours with the effect being dose dependent at the 4 th and 5 th hours. There were remarkable reductions of paw edema in the rats.

Conclusion: Allophylus africanus leaves has anti-inflammatory activity which explains the basis of its use in traditional medicine in the management of inflammation and related inflammatory disorders.
\end{abstract}

Implication for health policy/practice/research/medical education:

Allophylus africanus leaves have anti-inflammatory activity which explains the basis of its use in traditional medicine in the management of inflammation but caution is required due to its slight toxic effects. This knowledge can be tapped to formulate new agents to treat inflammatory and related inflammatory disorders.

Please cite this paper as: Ibrahim FS, Mohammed Z, Nuhu A, Shehu S, Ilyas N. Acute toxicity and anti-inflammatory activity of hydro-methanol leaves extract of Allophylus africanus Beauv in rats. J Herbmed Pharmacol. 2018;7(2):119-123. doi: 10.15171/ jhp.2018.20.

\section{Introduction}

Traditional medicine includes diverse health practices, approaches, knowledge and beliefs (1). The use of traditional medicines and medicinal plants in most developing countries as therapeutic agents for the maintenance of good health has been widely observed (2), with herbal medicine being an integral element, meet about $75 \%$ of the population's health care needs in Nigeria and up to $80 \%$ in Africa (3). The only true medicines ever used initially are plants (4) and some chemically useful plant drugs have been identified from the lead provided by their ethno-medical uses (5). Inflammation is a protective response that involves immune cells, blood vessels and molecular mediators and its disorders bring about enormous array of human diseases (6). The major classes of drugs to suppress inflammation are non-steroidal anti-inflammatory drugs (NSAIDS) and corticosteroids but their toxic adverse effects such as epigastric distress, peptic ulceration, osteoporosis, and iatrogenic Cushing's syndrome have limited their uses $(7,8)$. There is hence, a need to intensify researches for plant based antiinflammatory agents that are efficacious, safe, affordable, and accessible for patients.

Allophylus africanus is a specie of the genus Allophylus of the family Sapindaceae. It is a shrub that grows in the reverine thickest, open wood land and forest edges at 
altitudes of $960-1540 \mathrm{~m}$. It is widely distributed throughout tropical Africa (9). In Nigeria, it is locally known as Akanro, Akaraesu (in Yoruba), Akaito (in Igbo), Karki (in Hausa) and Ebe/ukpe (in Esan tribe in Edo state). In ethno-medicine, the boiled leaves are used in aches, fever and rheumatic pains (10), in gout, hemorrhoids (9) while root and twigs are used for diarrhea, dental and oral health care (10).

Previous pharmacological studies on the leaves extract of this plant showed that it possessed antimalarial, antimicrobial and anti-oxidant activities (11). The present study was carried out to evaluate the acute toxicity and anti-inflammatory effects of the extract in animal model, so as to validate the ethno-medicinal claim of the use of the plant in treatment of inflammation.

\section{Materials and Methods}

Collection, identification and preparation of the plant material

Fresh leaves of A. africanus were collected from "Samaru" village, Zaria, Kaduna State, Nigeria in March, 2014. The plant leaves were identified by Mallam Musa of the herbarium section of the Department of Biological Sciences, Ahmadu Bello University Zaria and a voucher specimen was deposited there with number 1540 .

The plant leaves were cleaned, air dried under shade and powdered using mortar and pestle to a suitable size and stored in appropriate container for further use.

\section{Extraction procedure}

Analytical grade solvents and freshly prepared solutions were used throughout the study. One thousand gram $(1000 \mathrm{~g})$ of the air dried powdered plant material was extracted by cold maceration in hydro-methanol mixture (methanol-water 80:20 v/v) for 120 hours using $5 \mathrm{~L}$. The filtrate obtained was concentrated to dryness in a rotor evaporator under vacuum and later in oven $\left(45^{\circ} \mathrm{C}\right)$. The dried powder was used for toxicological tests and anti-inflammatory activity (12). Qualitative phytochemical screening

Preliminary phytochemical screening of the aqueous methanol leaf extract was carried out for detection of carbohydrates, tannins, steroids/triterpenes, glycosides, flavonoids, alkaloids using standard test methods (13-15).

\section{Experimental animals}

Adult rats of both sexes (95-105 g) were obtained from National Institute for Trypanosomiasis Research (NITR), Kaduna State, Nigeria and kept in the animal house of the Department of Pharmacology and Therapeutics, Ahmadu Bello University, Zaria. The animals were maintained under standard conditions (12 hours light/12 hours dark cycle, temperature of $37 \pm 2^{\circ} \mathrm{C}, 35-60 \%$ humidity). The rats were fed with standard (grower) mash (Vital feed,
Jos, Nigeria) and water - ad libitum. Ethical rules guiding the use of animals for the experimentation were strictly adhered to (16) and with approval of Animal Ethics and Care Committee, Ahmadu Bello University, Nigeria (ABUCAUC/2016/018).

\section{Acute toxicity study}

The acute toxicity study of the aqueous methanol leaves extract of $A$. africanus was determined using previously described method (17). The study was carried out in two phases. The first phase consisted of 9 rats divided into 3 groups of three rats each and were treated with the aqueous methanol extract at doses of 10, 100 and 1000 $\mathrm{mg} / \mathrm{kg}$ body weight per oral. They were observed for 24 hours for signs and symptom of toxicity and death. In the second phase, three rats divided into 3 groups of one rat each were treated with the aqueous methanol extract at doses of 1600, 2900 and $5000 \mathrm{mg} / \mathrm{kg}$ body weight per oral and observed for 24 hours for signs and symptom of toxicity and death. The oral median lethal dose $\left(\mathrm{LD}_{50}\right)$ was calculated as the geometric mean of the minimum toxic dose and maximum tolerated dose.

Anti-inflammatory study

Thirty adult rats of both sexes of weight ranges (85-105 g) were divided into five groups of six animals each. Stock solution of the extract, aspirin and carrageenan were prepared. To group 1 of the animals, $1 \mathrm{~mL} / \mathrm{kg}$ of normal saline (negative control) was administered to each animal. To group II, aspirin (positive control) at dose of 300mg/ $\mathrm{kg}$ was administered. To groups III, IV and V, the extracts at doses 250, 500 and $1000 \mathrm{mg} / \mathrm{kg}$ were administered, respectively. After an hour, $0.1 \mathrm{ml}$ of sterile saline suspension of $1 \%$ carrageenan was injected into the sub planter surface of the left hind paw of all animals in each group. Paw size was measured using venier caliper at time $0,1,2,3,4$ and 5 hours after carrageenan administration. The percentage inhibition (PI) at each time interval was calculated (18).

$$
P I=\frac{\text { Control group }- \text { treated group }}{\text { Control group }} \times 100
$$

\section{Statistical analysis}

The results were expressed as mean \pm standard error of the mean (SEM) for all values. The data were statistically analyzed using one-way ANOVA (SPSS version 20.0) followed by Tukey's post hoc multiple comparison tests. The results were considered to be significant at $\mathrm{P}<0.05$.

\section{Results}

\section{Extraction yield}

The total solid of $A$. africanus crude extract recovered from maceration was $71 \mathrm{~g}$. The extract was dark green in color with pleasant smell and hard. 
Qualitative phytochemical screening

The results of the phytochemical screening of aqueous methanol leaves extract of $A$. africanus revealed the presence of secondary metabolites namely carbohydrates, tannins, steroids/triterpenes, flavonoids, alkaloids, cardiac glycosides and absent of saponins as shown in Table 1.

\section{Acute toxicity}

The acute toxicity of the extract was done per oral in rats. The $\mathrm{LD}_{50}$ was found to be $3807.89 \mathrm{mg} / \mathrm{kg}$ (the following formula) and there was death of an animal at dose 5000 $\mathrm{mg} / \mathrm{kg}$ in phase II (Table 2).

Anti-inflammatory activity of aqueous methanol leaves extract of Allophylus africanus

In the normal saline treated rats, sub-planter injection of $1 \%$ carrageenan suspension produced a local edema reaching its maximum effect at 3 hours. The aqueous methanol extract at doses $250 \mathrm{mg}$ and $1000 \mathrm{mg} / \mathrm{kg}$ was able to significantly produce anti-inflammatory effect (at the 3rd, 4th and 5th hours). At the 4th and 5th hours, the effect was dose dependent. The extract at dose $1000 \mathrm{mg} /$ $\mathrm{kg}$ showed higher inhibition of induced edema compared to standard drug (aspirin) at the 5th hour as shown in Table 3.

\section{Discussion}

Preliminary phytochemical screening provides a brief idea about the qualitative nature of active phytochemical constituents present in plant extract. The result of the preliminary phytochemical screening of the aqueous methanol extract indicated the presence of carbohydrates, steroids, triterpenes, glycosides, tannins, flavonoids and alkaloids (Table 1). These results other than conforming the previous findings (11) which reported the presence of tannins, saponins, flavonoids and carbohydrates in A. africanus plant, were necessary for standardization of the plant. These secondary plant metabolites are known to have various pharmacological effects and may be responsible for various activities of $A$. africanus.

The acute toxicity of the extract was done per oral in rats. The median lethal dose $\mathrm{LD}_{50}$ of aqueous methanol leaves extract of $A$. africanus was found to be $3.807 .89 \mathrm{mg} / \mathrm{kg}$. This suggests that the extract is slightly toxic, based on the recommended classification (19) which states that substances with $\mathrm{LD}_{50}$ values of 2000 to $5000 \mathrm{mg} / \mathrm{kg}$ body weight is slightly toxic.

The hydro-methanolic leaf extract of $A$. africanus was able to significantly $(P<0.05)$ produce anti-inflammatory effect at the peak of carrageenan induced edema but with less activity than that of the standard anti-inflammatory agent (aspirin). The extract at doses $250 \mathrm{mg} / \mathrm{kg}$ and $1000 \mathrm{mg} / \mathrm{kg}$ was able to significantly produce anti-inflammatory effect at the 3rd, 4th and 5th hours with the effect being dose dependent at the 4 th and 5 th hour. The extract however
Table 1. Qualitative phytochemical constituent of aqueous methanol extract of Allophylus africanus leaves

\begin{tabular}{ll}
\hline Constituents & Inference \\
\hline Carbohydrates & + \\
Tannins & + \\
Saponins & - \\
Steroids/Triterpenes & + \\
Flavonoids & + \\
Cardiac glycosides & + \\
Alkaloids & + \\
\hline
\end{tabular}

Table 2. Median lethal dose $\left(\operatorname{LD}_{50}\right)$ of aqueous methanol leaves extract of Allophylus africanus administered orally

\begin{tabular}{lll}
\hline Experiment & Dose $(\mathbf{m g} / \mathbf{k g})$ & Number of dead mice after $\mathbf{2 4} \mathbf{~}$ \\
\hline Phase I & 10 & $0 / 3$ \\
& 100 & $0 / 3$ \\
& 1000 & $0 / 3$ \\
Phase II & 1600 & $0 / 1$ \\
& 2900 & $0 / 1$ \\
& 5000 & $1 / 1$ \\
\hline
\end{tabular}

$\mathrm{LD}_{50}=\sqrt{\text { Min.toxic dose } \times \text { Max.tolerated dose }}$

$\mathrm{LD}_{50}=\sqrt{(2900 \times 5000)}$

$\mathrm{LD}_{50}=3807.89 \mathrm{mgkg}^{-1}$

showed higher inhibition significantly $(P<0.01)$ of induced edema compared to the standard drug (Aspirin) at the 4th and 5 th hour with percentage inhibition of $62.57 \%$ and $82.88 \%$ respectively (Table 3 ). Inflammation induced by carrageenan is thought to be biphasic (20). The early phase is mediated by histamine, serotonin, and prostaglandin increased synthesis in the damaged surrounding tissues. The late phase is sustained by prostaglandins produced by tissue macrophages and prostaglandins released and mediated by polymorhphonuclear cells, leukotrines and bradykinins. Mona et al (6) reported that secondary metabolites like flavonoids, tannins, saponins, alkaloids found in plants have anti-inflammatory effects. The mechanism underlying the anti-inflammatory effects of tannins includes the scavenging of radicals and inhibition of the expression of inflammatory mediators such as some cytokines, inducible nitric-oxide synthase and COX-2 (21). Some flavonoids have anti-inflammatory property and produce activity by inhibiting molecular targets of pro-inflammatory mediators in inflammatory responses (21). Wang et al (22) has reported that the antiinflammatory effects of steroids could be attributed to a counter-irritation effect.

\section{Conclusion}

The aqueous methanol extract of $A$. africanus leaves had 
Ibrahim et al

Table 3. Effect of the aqueous methanol extract of Allophylus africanus on carrageenan induced paw edema in rats

\begin{tabular}{|c|c|c|c|c|c|c|}
\hline \multirow{2}{*}{ Treatment } & \multirow{2}{*}{ Dose } & \multicolumn{5}{|c|}{ Mean paw edema thickness in diameters \pm SEM $(\mathrm{mm})$} \\
\hline & & $1 \mathrm{~h}$ & $2 \mathrm{~h}$ & $3 \mathrm{~h}$ & $4 \mathrm{~h}$ & $5 \mathrm{~h}$ \\
\hline Normal saline & $1 \mathrm{~mL} / \mathrm{kg}$ & $1.76 \pm 0.26$ & $2.29 \pm 0.15$ & $2.40 \pm 0.37$ & $1.71 \pm 0.35$ & $1.11 \pm 0.17$ \\
\hline Aspirin & $300 \mathrm{mg} / \mathrm{kg}$ & $0.89 \pm 0.18 *(49.43)$ & $1.36 \pm 0.23 *(40.61)$ & $0.94 \pm 0.06 * *(60.83)$ & $0.75 \pm 0.11^{*}(56.14)$ & $0.58 \pm 0.12 *(47.75)$ \\
\hline Extract & $250 \mathrm{mg} / \mathrm{kg}$ & $1.46 \pm 0.19(17.05)$ & $1.65 \pm 0.17(27.95)$ & $1.39 \pm 0.19 *(42.08)$ & $1.26 \pm 0.16(26.32)$ & $0.58 \pm 0.12(47.75)$ \\
\hline Extract & $500 \mathrm{mg} / \mathrm{kg}$ & $1.46 \pm 0.16(17.05)$ & $1.99 \pm 0.24(13.10)$ & $1.68 \pm 0.22(30.0)$ & $0.95 \pm 0.23(44.44)$ & $0.60 \pm 0.18(45.95)$ \\
\hline Extract & $1000 \mathrm{mg} / \mathrm{kg}$ & $1.22 \pm 0.15(30.68)$ & $1.81 \pm 0.24(20.96)$ & $1.40 \pm 0.25^{*}(41.67)$ & $0.64 \pm 0.24 *(62.57)$ & $0.19 \pm 0.13^{* *}(82.88)$ \\
\hline
\end{tabular}

$* P<0.05$, compared with normal saline group, $* * P<0.01$ compared with normal saline group (One-way ANOVA followed by Tukey's post hoc multiple comparison test).

Data expressed as Mean \pm SEM. values given in parentheses represent $\mathrm{PI}-$ Percentage inhibition.

anti-inflammatory activity which may explain the basis of its use in traditional medicine in the management of inflammation and related inflammatory disorders. The significant anti-inflammatory activity of the extract observed might be associated to the secondary metabolites present in the plant and this may proffer scientific basis for its use. But, systemic important dose should be avoided due to the toxicity risk. Further bioassay-led fractionation and isolation of active principles are to be undertaken.

\section{Acknowledgement}

The authors appreciate the efforts of Mall. Kabiru Ibrahim and Kamilu Mahmud Zaria of research laboratory, Department of Pharmacognosy and Drug Development Ahmadu Bello University, Zaria, Nigeria for their support in handling some of the facilities used in carrying out this research work.

\section{Authors' contributions}

ISF,ZMandNIconceived theideaanddesigned thestudy.AN and SS assisted during the literature search, data analysis and preparation of the manuscript. All read and confirmed the final version of the manuscript for publication.

\section{Conflict of interests}

The authors declare no conflict of interest.

\section{Ethical considerations}

Ethical issues have been observed by the authors. The protocol was confirmed by Animal Ethics and Care Committee, Ahmadu Bello University, Nigeria (ABUCAUC/2016/018).

\section{Funding/Support}

This research had no financial support.

\section{References}

1. World Health Organization. World Health Report: Reducing risks and promoting healthy life. Geneva: World Health Organizations; 2002.
2. Nuhu A, Danmalam UH, Ilyas $N$, Zakariya AM, Abdulhamid Z, Abubakar AZ. Pharmacognostic evaluation of the leaves and Sstem-bark of Commiphora africana (A. Rich) Engl. (Burseraceae). Niger J Nat Prod Med. 2016;20(1):56-60. doi: 10.4314/njnpm.v20i1.10.

3. Adesina BT, Oguntuga OA, Rami KAA, Ogunremi JB. Guide to large scale productions of Moringa oleifera (Lam) for sustainable aquaculture development in Nigeria: prospects and challenges. Agrosearch. 2013;13(3):186-94. doi: 10.4314/agrosh.v13i3.2S.

4. Kadans JM. Modern encyclopedia of herbs, with the herb-o-matic locator index. New York: Parker Publishing Company Inc; 1970.

5. Mate GS, Naikwade NS, Magdum CS, Chowki AA, Patil SB. Evaluation of anti-nociceptive activity of Cissus quadrangularis on albino mice. Int J Green Pharm. 2008;2(2):118-21.

6. Salih M, Ahmed WJ, Garelnabi E, Osman Z, Osman B, Khalid HS, et al. Secondary metabolites as antiinflammatoryagents. The Journal of Phytopharmacology. 2014;3(4):275-85.

7. Grosser T, Smyth E, Fitzgerald GA. Goodman and Gilman's the pharmacological basis of therapeutics. 12th ed. In: Brunton L, ed. Anti-inflammatory, Antipyretic and analgesic agents: Pharmacotherapy of Gout. New York: McGrawHill; 2011:959-1000.

8. Chorousus GP. Basic and clinical pharmacology. 12th ed. In: Katzung BG, Masters SB, Trevor AJm eds. Adrenocorticosteroids and adrenocortical antagonists. New York: McGraw-Hill; 2012:697-711.

9. Burkill HM. The useful plants of west tropical Africa. London: Royal Botanic Garden, Kew; 1985:181-2.

10. Idu M, Umweni AA, Odaro T, Ojelede L. Ethnobotanical plants used for oral Health care among the Esan tribe of Edo state, Nigeria. Ethnobotanical Leaflets. 2009;2009(13):548-63.

11. Oladosu IA, Balogun SO, Ademowo GO. Phytochemical screening, antimalarial and histopathological studies of Allophylus africanus and Tragia benthamii. Chin J Nat Med. 2013;11(4):371-6. doi: 10.1016/s18755364(13)60054-0.

12. Kokate CK. Practical pharmacognosy. New Delhi, India: Vallabh Prakashan; 2003:107-11.

13. Harborne JB. Methods of plant analysis. In: 
Phytochemical Methods. Netherlands: Springer; 1973: 1-32.

14. Evans WC. Trease and Evans Pharmacognosy. 15th ed. London: W.B. Saunders Ltd; 2002:191-393.

15. Sofowora A. Medicinal Plants and Traditional Medicine in Africa. 3rd ed. Ibadan: Spectrum Books; 2008.

16. DHHS. Guide for the care and use of laboratory animals. Institute of Laboratory Animal Resources Commission on Life Sciences, National Research Council. Washington, D.C: National Academy; 1985.

17. Lorke D. A new approach to practical acute toxicity testing. Arch Toxicol. 1983;54(4):275-87.

18. Winter EA, Risely EA, Nuss, GB. Anti-inflammatory therapy. Proceedings of Society for Experimental Biology and Medicine (New York). 1963;141:369-76.
19. Loomis TA, Hayes AW. Loomis Essentials of Toxicology. 4th ed. California: Academic Press; 1996: 208-45.

20. Musa AM, Sule MI, Iliyas M, Iliya I, Yaro AH, Magaji MG, et al. Analgesic and anti-inflammatory agents. Journal of Phytoparmacology. 2010;3(4):275-85.

21. Fawole OA, Ndhlala AR, Amoo SO, Finnie JF, Van Staden J. Anti-inflammatory and phytochemical properties of twelve medicinal plants used for treating gastrointestinal ailments in South Africa. J Ethnopharmacol. 2009;123(2):237-43. doi: 10.1016/j.jep.2009.03.012.

22. Wang H, Gao J, Kou J, Zhu D, Yu B. Anti-inflammatory activities of triterpenoid saponins from Polygala japonica. Phytomedicine. 2008;15(5):321-6. doi: 10.1016/j.phymed.2007.09.014. 